\title{
Determination of the Concentration of Seawater Components Based on Upwelling Radiation Spectrum
}

\author{
M.E. Lee, E.B. Shybanov, E.N. Korchemkina, O.V. Martynov \\ Marine Hydrophysical Institute, Russian Academy of Sciences, Sevastopol, \\ Russian Federation \\ e-mail: michael.lee.mhi@gmail.com
}

\begin{abstract}
Results of seawater reflectance measurements carried out in the Black Sea coastal waters in the summer-autumn season, 2002-2014 on the oceanographic platform of the Experimental Department of MHI are discussed. The data were obtained using the spectrophotometer developed in the Marine Optics Department of MHI. Special measuring technique allows one to take into account the light reflected by the sea surface that eliminates necessity in sub-surface probing and provides higher accuracy as compared to the results of the model simulations. The measurements show that in the summer-autumn period the sea reflectance spectra are of almost constant shape with a smooth peak in the range $480-500 \mathrm{~nm}$. The peak values usually lie within between $1 \%$ (October) and $2 \%$ (July), except for the spectra measured during the coccolythophore bloom in 2012 when the peak values reached $6.6 \%$ (4.5\% on average). The semi-analytical algorithm of reflectance data processing permits to obtain inherent optical properties of seawater including the phytoplankton pigments' concentration, absorption by nonliving organic matter and scattering by marine particles, and also to detect the auxiliary photosynthetic pigments from the reconstructed phytoplankton absorption spectrum. Special optimization technique permitting to simplify and to stabilize calculations is introduced. The chlorophyll- $a$ concentrations obtained using the algorithm are in good agreement with direct biological data. Simultaneous measurements of reflectance and chlorophyll- $a$ concentration performed during the sub-satellite experiment in 2002-2004 have shown that discrepancy between the modeled and the measured concentrations was about $10 \%$. The considered method permits to carry out operational sub-satellite monitoring of marine environment and, in particular, to validate the algorithms for processing remote sensing data.
\end{abstract}

Keywords: seawater reflectance coefficient, spectrophotometer, chlorophyll- $a$, mineral suspension, coccolithophore, phytoplankton pigments.

DOI: $10.22449 / 1573-160 X-2015-6-15-30$

(C) 2015, M.E. Lee, E.B. Shybanov, E.N. Korchemkina, O.V. Martynov

(C) 2015, Physical Oceanography

Introduction. Optical methods are the most convenient for the global primary production and admixture content evaluation in the surface waters. Their advantage as compared with the labour-intensive and expensive surface-based oceanological observations lies in the efficiency, regularity and larger amounts of the information obtained. One of the most informative hydrooptical characteristics is the seawater reflectance coefficient, which is the ratio between irradiance upwelling from the sea and radiance of diffusely reflecting white screen.

Upwelling radiation spectrum depends on the presence in the water of the suspended particles and dissolved organic matters, such as mineral suspension of various origin, phytoplankton cells containing chlorophyll- $a$ and other pigments and also nonliving organic particles (detritus) and dissolved organic matter (yellow substance). At the same time the number of the unknown seawater characteristics exceeds the number of the measured parameters. Evaluation of the characteristics of the water masses based on reflectance data is the classical inverse problem. However, the algorithms for solving these problems and retrieving the PHYSICAL OCEANOGRAPHY NO. 6 (2015) 
concentrations of the admixtures from the upwelling radiance are insufficiently precise. Because of the regional seawater specificity, chlorophyll-a concentration evaluations based on the optical data, particularly the satellite ones, can differ significantly from the real values, especially in the coastal zone.

Spectrophotometers for measurement of the upwelling radiation spectrum are one of the basic hydrooptical instruments for carrying out the oceanographic subsatellite experiments for calibration of the new generation satellite scanners. That is why nowadays there appear a great amount of the works on the seawater reflectance coefficient measurement methodology, relevant instruments and algorithms for determination of the biooptical water parameters from the measurement results [1-11].

In the field the reflectance coefficient can be determined in different ways. One of the popular instruments on the primary stage of the research was the radiance meter [1 -5]. The process of measurements was performed in two stages: firstly the measurement of the radiance of the horizontal diffusely reflecting screen and then - the water mass radiance. During the remote measurements the sky radiance was also determined.

In some research the reflectance coefficient was obtained as a result of the simultaneous measurements by two sensors: downwelling irradiance meter and radiance meter, the upwelling radiance measurements being performed both remotely and directly in the water [6 - 11]. However, these two methods have severe requirements to the accuracy, long-term stability and linearity of the sensor characteristics. The measurements performed by one instrument are divided in time, and this circumstance implies additional limitations on the stability of the external weather conditions. During the determination by two different sensors small errors of the each sensor can lead to the inadmissible resultant errors. Moreover, for this kind of measurements the absolute calibration with high accuracy of the radiance and irradiance photometers is necessary, that is quite difficult to realize under field conditions nowadays.

To overcome the aforementioned difficulties the specific wide-range highstable photometers for sea reflectance determination have been developed in some countries. They measure simultaneously the downwelling irradiance, upwelling radiance, sky radiance by the same sensor, but through different optical channels. Application of these instruments increased the measurements quality, but the absolute calibration problems had not been solved, as each optical channel needed the individual calibration [6, $12-14]$.

Instruments. One of the most perfect instruments was developed in the Marine Optics and Biophysics Department of Marine Hydrophysical Institute RAS [15]. The multi-purpose spectrophotometer for seawater reflectance coefficient measurement permits to solve various subsatellite biooptical problems (Fig. 1). Spectral range of the instrument is $390-720 \mathrm{~nm}$, spectral resolution $-5 \mathrm{~nm}$, error $-3 \%$. There is the possibility provided for simultaneous measurement of the spectral radiance angular distribution of the upwelling seawater radiance or skylight radiance, normalized for the sea surface spectral irradiance. Calibration of the instrument was carried out by diffusely reflecting screen with known reflectance coefficient. 
There is also the possibility of the operation both from the board of the research vessel or the platform, and immediately from the sea surface on the hydrological stations. In the latter case the measurements permit to reduce up to minimum the mentioned methodological errors and obtain the control-calibrated data with the accuracy required to solve the biooptical problems. Remote sensing from the board of the research vessel or oceanographic platform provide larger information capability, but the accuracy of the measurements required for the subsatellite tasks can be reached only in fair weather, when the state of sea does not exceed $2-3$ points, and light conditions are quite stable. Under more rough waters, especially when the ripple takes place, the interferences related to the sun glints and reflection of the various sky parts from the choppy sea surface become so huge that they cannot be deleted by the simple spikes cull and special smoothing procedures.

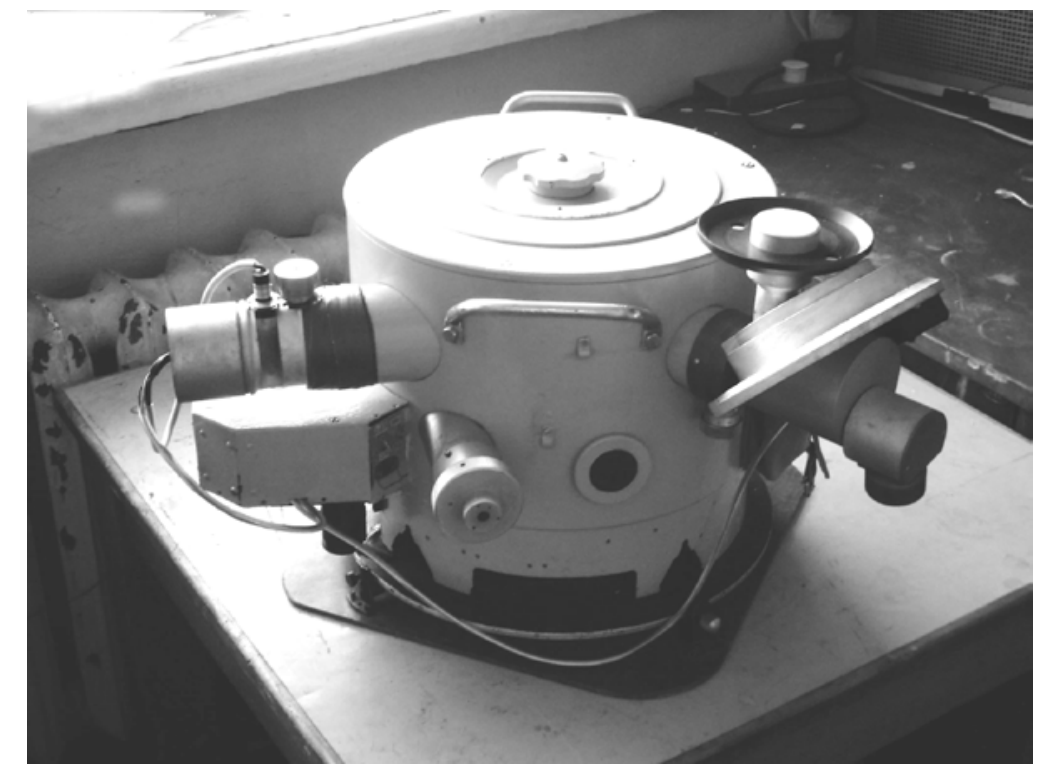

Fig. 1. Spectrophotometer for seawater reflectance coefficient measurements

Measuring from the board in the close-to-nadir direction, seawater reflectance coefficient is expressed by the following formula:

$$
\rho=\pi \frac{n^{2}}{T_{1} T_{2}} \frac{L_{\mathrm{u}}-r_{\mathrm{f}} L_{\mathrm{sk}}}{E_{\mathrm{d}}},
$$

where $n$ - the refractive index; $r_{\mathrm{f}}=0,02-$ Fresnel reflection coefficient at normal fall; $T_{1}$ - air-water interface transmittance; $T_{2}$ - water-air interface transmittance; $L_{\mathrm{u}}-$ upwelling sea reflectance; $L_{\mathrm{sk}}-$ zenithal sky diffuse radiation; $E_{\mathrm{d}}-$ sea surface irradiance.

However during such experiment the instrument case shadowing influence is rather great and to avoid it the measurements are carried out at $45^{\circ}$ angle to nadir. In this case Fresnel reflection coefficient cannot be accurately taken into account as PHYSICAL OCEANOGRAPHY NO. 6 (2015) 
it depends on the sea surface roughness, sky state (polarization, spectral and angular characteristics of diffuse radiation) and also on the measurements configuration. To determine the upwelling reflectance reflective constituent different techniques based both on simulation and specific measurement schemes have been developed [3, 4, 13, 14, 16, 17].

To use the given spectrophotometer the following measuring technique is applied. Having measured the seawater reflectance coefficient $\rho_{\text {sea }}$ (Fig. 2, on the left) the water-filled cell with absorbing walls and bottom is installed in the spectrophotometer field of view for measuring reflectance coefficient of the water surface $\rho_{\text {surf }}$ under the same radiance conditions (Fig. 2, on the right). Spectra $\rho_{\text {surf }}$ were then subtracted from the spectra $\rho_{\text {sea }}$. Thus, water mass reflectance coefficient $\rho_{\mathrm{w}}$ was determined:

$$
\rho_{\mathrm{w}}=\rho_{\text {sea }}-\rho_{\text {surf }} .
$$

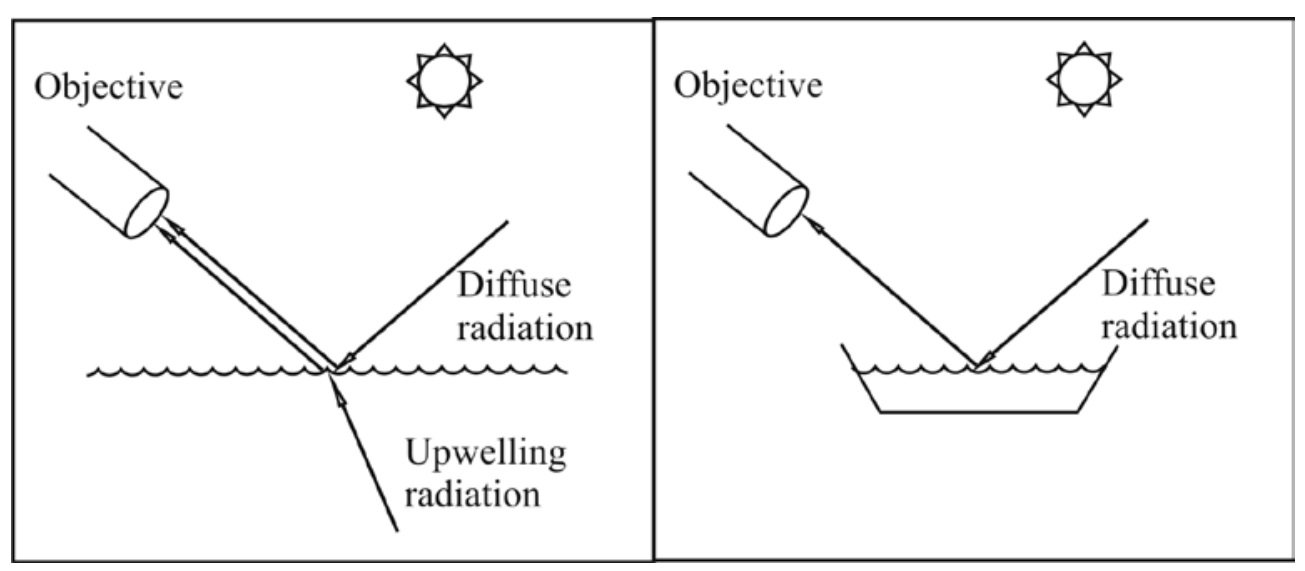

Fig. 2. Seawater reflectance coefficient measurement procedure

Hereinafter the value $\rho_{\mathrm{w}}$ will be called seawater reflectance coefficient.

Despite the fact that the measurement procedure is somewhat complicated, this method allows to take into account the reflected constituent. The difference in the surface roughness in the sea and in the cell appears as a wider scatter of the measurement data $\rho_{\text {sea }}$, which is neutralized by spikes rejection and averaging of the several successive measurements.

Data. In 2002 - 2014 on oceanographic platform (urban village Katsively) a series of complex subsatellite experiments was carried out in order to determine the seawater biooptical characteristics including reflectance (Fig. 3). According to the results of these measurements it can be concluded that the reflectance spectra in the summer and autumn have almost constant shape with a maximum in the range of $480-500 \mathrm{~nm}$. Information on the data obtained is given in the table and in Fig. 4. The maximum value changed from $1 \%$ in October to $2 \%$ in July. The data measured during the strongest in recent years coccolithophore bloom [18] in July 2012 are an exception, when the maximum reflectance value averaged $4.5 \%$, and the individual values reached $6.6 \%$, while the shape of the measured spectra did not change. 
Direct sunlight

Skylight

Reflectance

meter

Light reflected

by sea surface

Secchi disk

Attenuation

Seawater

meter

radiation

Polar

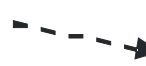

radiation

nephelometer

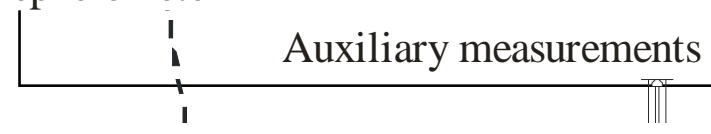

Fig. 3. Complex experiment on the oceanographic platform

Data on seawater reflectance coefficient spectrum measurements on the oceanographic platform (urban village Katsively)

\begin{tabular}{c|c|c|c|c|c}
\hline Year & Date & $\begin{array}{c}\text { Amount of } \\
\text { measurements }\end{array}$ & Year & Date & $\begin{array}{c}\text { Amount of } \\
\text { measurements }\end{array}$ \\
\hline 2002 & $28.07-15.08$ & 18 & 2008 & $10.09-13.09$ & 21 \\
2003 & $16.07-28.07$ & 41 & 2010 & $11.08-16.08$ & 35 \\
2004 & $31.08-13.09$ & 41 & 2010 & $23.09-28.09$ & 37 \\
2007 & $08.07-21.07$ & 86 & 2012 & $07.07-16.07$ & 72 \\
2007 & $04.10-12.10$ & 44 & 2014 & $11.08-14.08$ & 19 \\
\hline
\end{tabular}

PHYSICAL OCEANOGRAPHY NO. 6 (2015) 


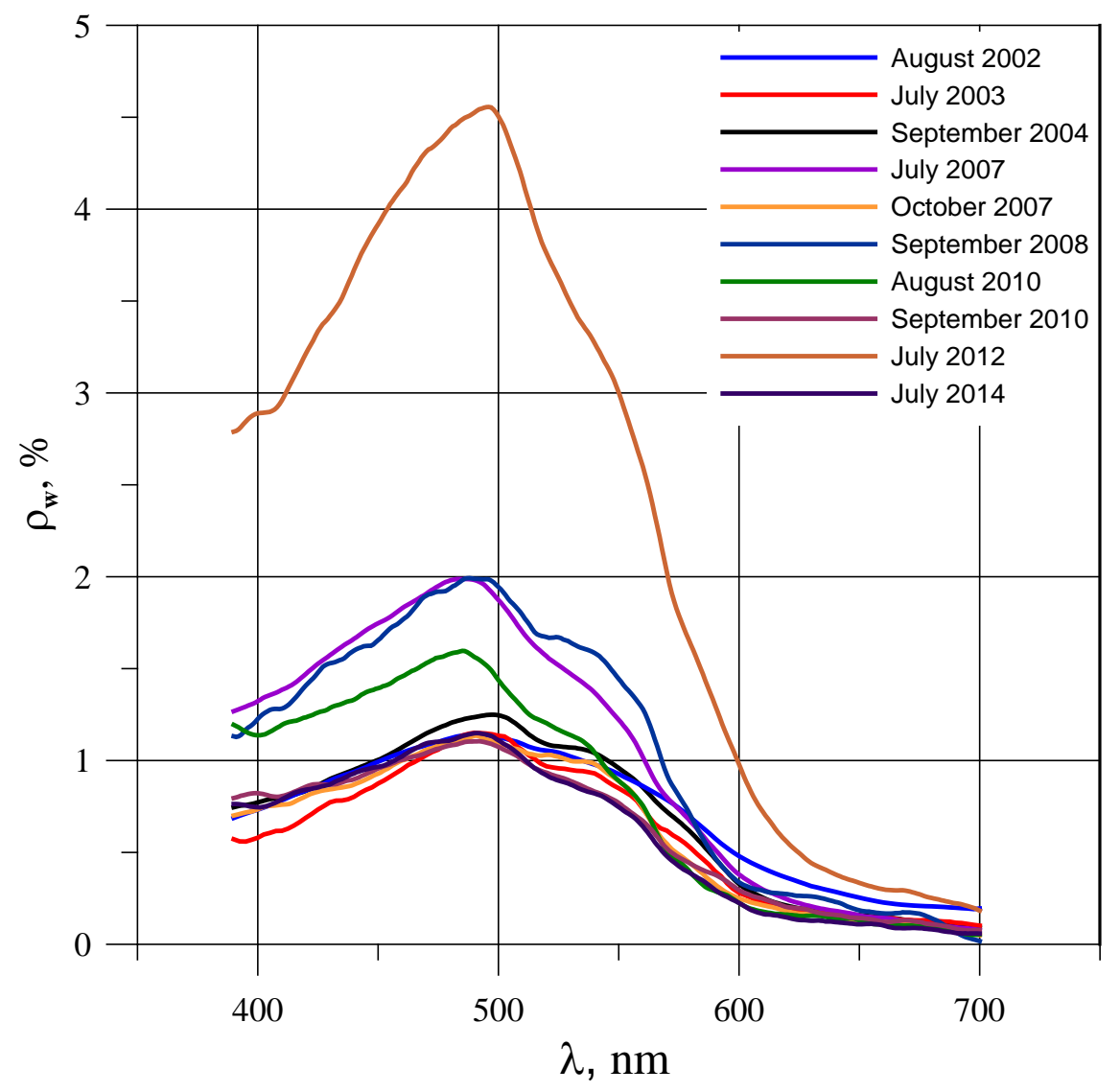

Fig. 4. Average seawater reflectance coefficient spectra

Observation of the bloom was of particular interest because the increase of the upwelling radiance turned out to be so strong that the automatic satellite data processing programs recognized the area of bloom as cloudiness (Fig. 5).

Emiliania huxleyi is a species of coccolithophore, unicellular algae cell sized $5-8$ microns, on the surface of each cell there are calcareous disks (coccoliths) of 1 - $2 \mathrm{~mm}$ [19]. In the Black Sea Emiliania huxleyi are $90-99 \%$ of the total coccolithophore [20]. During life-cycle the cell casts off coccoliths several times, resultsing in the multiple growth of the coarse mineral particles amount in the water and, consequently, in the increase of the light scattering without substantial increase of the absorption. Weak spectral selectivity of coarse particles scattering leads to distinctive albescent shade of the water that allows a visual detection of coccolithophore bloom. Backscattering growth causes increase of seawater upwelling radiance and reflectance coefficient measured in the present experiment. 


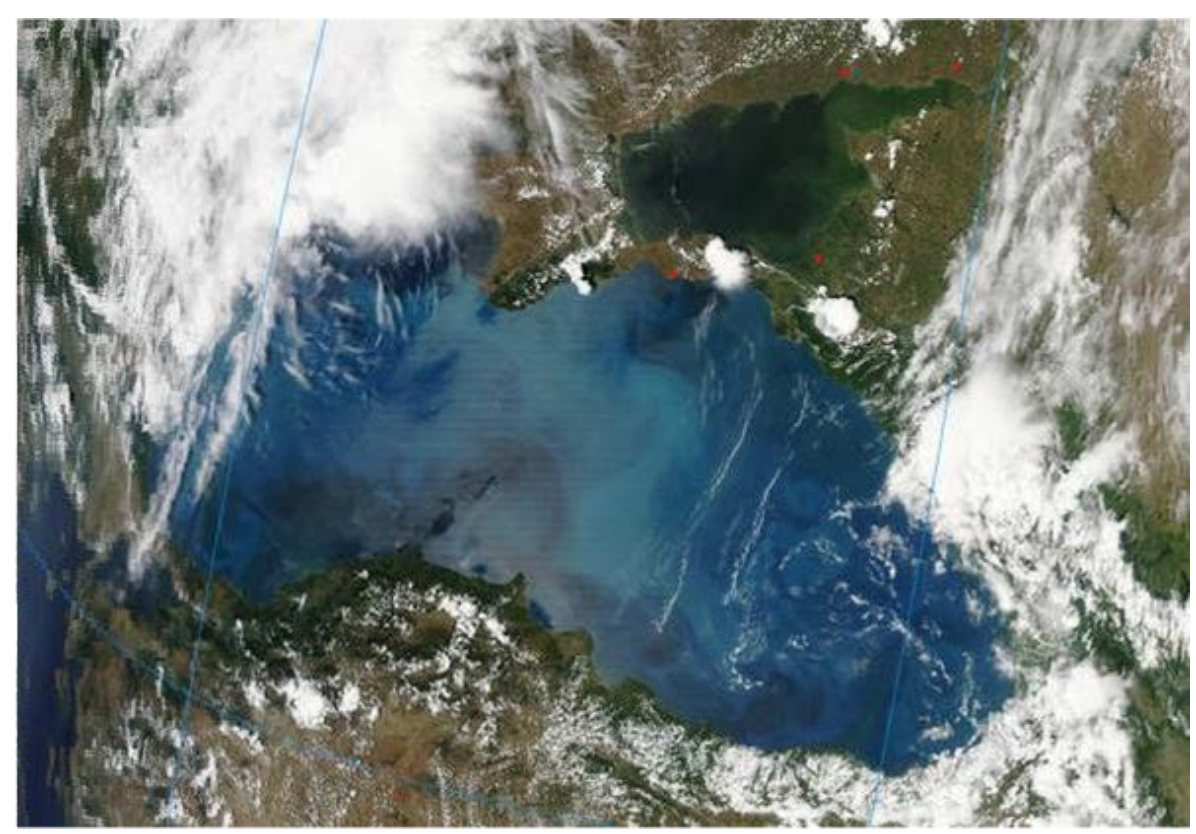

$a$

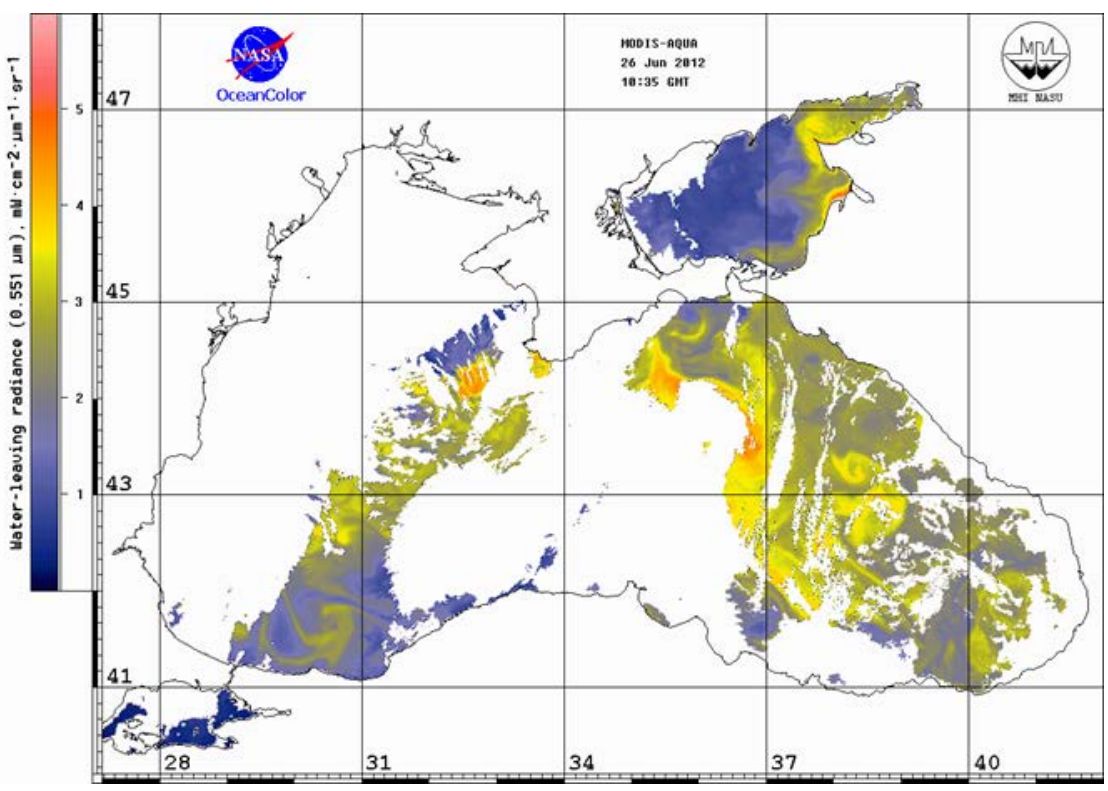

$b$

Fig. 5. Satellite image of the Black Sea $(a)$ and after applying the cloud mask $(b)$ dated 26.06.12 (http://blackseacolor.com) 
Methodology. During solving the inverse problems of finding the seawater optical properties the reflectance is generally related to the ratio $\frac{b_{\mathrm{b}}}{a}$, where $b_{\mathrm{b}}-$ seawater backscattering, $a-$ absorption:

$$
\rho(\lambda)=k \frac{b_{\mathrm{b}}(\lambda)}{a(\lambda)} .
$$

Usually backscattering and absorption spectra are represented as the sum of the respective components, and then the reflectance coefficient spectrum is described by the following formula

$$
\rho(\lambda)=k \frac{b_{\mathrm{bw}}(\lambda)+b_{\mathrm{bp}}\left(\lambda_{0}\right)\left(\lambda_{0} / \lambda\right)^{\nu}}{a_{\mathrm{w}}(\lambda)+C_{\mathrm{chl}} a_{\mathrm{chl}}^{*}(\lambda)+C_{\mathrm{ddm}} \mathrm{e}^{-\alpha\left(\lambda-\lambda_{0}\right)}},
$$

where $k=0,15$ [21]; $\quad b_{\mathrm{bw}}(\lambda)$ - pure water backscattering index; $v$ backscattering spectral slope , depending on the size of the particles; $a_{\mathrm{w}}(\lambda)$ - pure water absorption coefficient [22]; $a_{\mathrm{chl}}^{*}(\lambda)$ - specific absorption spectrum of the phytoplankton pigments [23]; $\alpha$ - nonliving organic matter absorption spectral slope parameter. Model parameters: $b_{\mathrm{bp}}\left(\lambda_{0}\right)$ - backscattering coefficient of the suspended particles at the wavelength $\lambda_{0}=400 \mathrm{~nm}$, concentration of the phytoplankton pigments $C_{\mathrm{chl}}$ and nonliving organic matter absorption $C_{\mathrm{ddm}}$ are calculated by optimization in the specially developed iterative procedure discussed below.

From a mathematical point of view, the calculation of the reflectance coefficient model spectrum $\rho_{\mathrm{m}}$ parameters based on the experimental data $\rho_{\mathrm{e}}$ is consists in finding the minimum of the expression

$$
f=\sum_{\lambda_{1}}^{\lambda_{2}}\left[\rho_{\mathrm{e}}(\lambda)-\rho_{\mathrm{m}}(\lambda)\right]^{2}
$$

as the function $f$ of the variables $b_{\mathrm{bp}}\left(\lambda_{0}\right), C_{\mathrm{ddm}}$ and $C_{\mathrm{chl}}$ within the whole spectral range, i.e. to the solving of the system of equations

$$
\left\{\begin{array}{l}
\frac{\partial f\left(b_{\mathrm{bp}}, C_{\mathrm{chl}}, C_{\mathrm{ddm}}\right)}{\partial b_{\mathrm{bp}}}=0, \\
\frac{\partial f\left(b_{\mathrm{bp}}, C_{\mathrm{chl}}, C_{\mathrm{ddm}}\right)}{\partial C_{\mathrm{chl}}}=0, \\
\frac{\partial f\left(b_{\mathrm{bp}}, C_{\mathrm{chl}}, C_{\mathrm{ddm}}\right)}{\partial C_{\mathrm{ddm}}}=0 .
\end{array}\right.
$$

By minimizing the deviation of the experimental data from the model spectra, we eliminate only the random error of the experiment, considering the model representation 
absolutely reliable. However, the model can not describe all the possible features of the absorption and scattering of the dissolved and suspended matters.

The absorption bands of the yellow substance and phytoplankton pigments overlap. Besides, the larger concentrations of chlorophyll- $a$ match the larger concentrations of dissolved organic matter only on average. Therefore it is not always possible to find out what determines the shape of the reflectance coefficient spectrum - the presence of the yellow substance or phytoplankton pigments.

The developed algorithm solves this problem by isolating sites in the visible spectrum; the concentration of each substance is determined on the spectral site where its absorption is most significant in comparison with the influence of other components. This makes possible to distinguish the absorption spectra, based on the known general laws of their behavior. Mathematically, it looks like the division of the system of equations (6) as follows:

$$
\begin{aligned}
& \left.\frac{\partial f\left(b_{\mathrm{bp}}, C_{\mathrm{chl}}, C_{\mathrm{ddm}}\right)}{\partial b_{\mathrm{bp}}}\right|_{\lambda_{5}} ^{\lambda_{6}}=0, \\
& \left.\frac{\partial f\left(b_{\mathrm{bp}}, C_{\mathrm{chl}}, C_{\mathrm{ddm}}\right)}{\partial C_{\mathrm{chl}}}\right|_{\lambda_{3}} ^{\lambda_{4}}=0, \\
& \left.\frac{\partial f\left(b_{\mathrm{bp}}, C_{\mathrm{chl}}, C_{\mathrm{ddm}}\right)}{\partial C_{\mathrm{ddm}}}\right|_{\lambda_{1}} ^{\lambda_{2}}=0,
\end{aligned}
$$

i. e. at each site the minimization is performed by one variable at a time, and the remaining parameters are considered constant. This greatly simplifies the calculations and stabilizes the solution of the inverse problem.

Values $\lambda_{i}$ have been found in the numerical experiment described in [24]. The spectral site $390-410 \mathrm{~nm}$ is used for the nonliving organic matter absorption, 420 - $460 \mathrm{~nm}$ - for chlorophyll- $a$ concentration and $460-650 \mathrm{~nm}$ - for particles scattering. At the first stage the minimum of the expression (5) as a function of the variable $b_{\mathrm{bp}}\left(\lambda_{0}\right)$ is found, in the first approximation the dissolved organic matter and pigment concentration are taken to be zero. Then the expression (5) is minimized as the function of $C_{\text {chl }}$, and concentration of the pigments is calculated taking into account the obtained suspension scattering value; in the similar manner the concentration of dissolved organic matter $C_{\mathrm{ddm}}$ is found.

On the second and following stages the values $b_{\mathrm{bp}}\left(\lambda_{0}\right)$ are determined applying the values $C_{\mathrm{chl}}$ and $C_{\mathrm{ddm}}$, calculated during the previous stage. Thus, we obtain an iterative algorithm that allows to calculate the parameters $C_{\mathrm{ddm}}, b_{\mathrm{bp}}\left(\lambda_{0}\right)$ and $C_{\mathrm{chl}}$. To achieve the stop condition $\left|C_{\mathrm{chl}}^{i}-C_{\mathrm{chl}}^{i-1}\right|<0,001$ up to 10 iterations are needed.

Results and discussion. The concentrations of phytoplankton pigments calculated from the reflectance coefficient spectra were compared with data from the field measurements of chlorophyll- $a$ [25], performed simultaneously with the 
optical ones. The result of this comparison is shown in Fig. 6. At high concentrations of pigments the decrease of the calculated concentrations compared with those measured is observed. This is due to the fact that the applied pigment absorption model is linear and does not take into account "package effect".

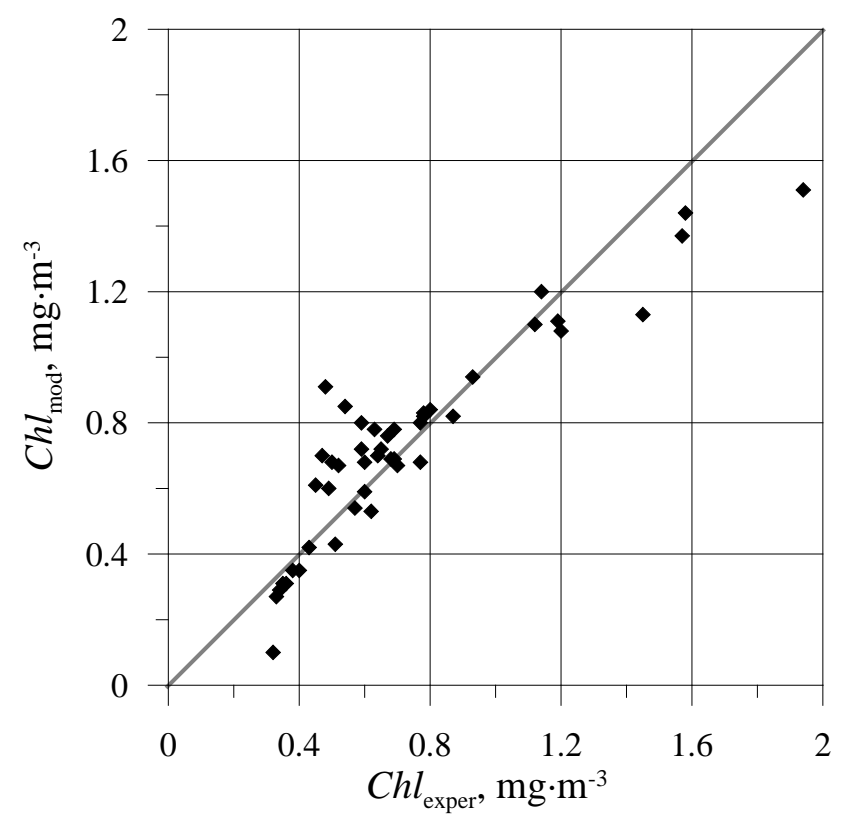

Fig. 6. Comparison of the calculated concentrations of phytoplankton pigments $\left(C h l_{\text {mod }}\right)$ with the measured chlorophyll- $a$ concentrations ( $C h l_{\text {exper }}$ ) according to the data of $2002-2004$

The main source of errors of such method of the unknown concentration calculating is a wrong assessment of the input model parameters, such as spectral slopes $\alpha$ and $v$, as well as the specific absorption of $a$-chlorophyll. Previously, it was shown that the nonliving organic matter absorption spectral slope has the greatest influence on the accuracy of retrieving. It is known from the literature sources [25 - 27], that the total value of the spectral slope of the total dissolved organic matter and detritus absorption may vary within $0.015-0,02 \mathrm{~nm}^{-1}$, which leads to $25 \%$ change of calculated chlorophyll- $a$ concentration. In the resent work the spectral slope $\alpha$ is considered constant and equals $0,017 \mathrm{~nm}^{-1}$.

Observing coccolithophore bloom in 2012 due to the absence of direct measurements of the chlorophyll- $a$ concentration the comparison of the results with the satellite data (averaged over several pixels) obtained in the area of oceanographic platform was performed. Fig. 7 shows time dependence of the values $C_{\mathrm{chl}}$. We can see that coccolithophore bloom does not lead to a significant increase in the absorption of phytoplankton pigments. This is most likely because the calcareous shell of coccolithophore hinders the penetration of light into the cell. At the same time the average concentration was $\sim 0.5 \mathrm{mg} \cdot \mathrm{m}^{-3}$, which is slightly higher than the average values for the summer period, but such overstating of chlorophyll- $a$ content is consistent with the observations of the other authors [28]. 


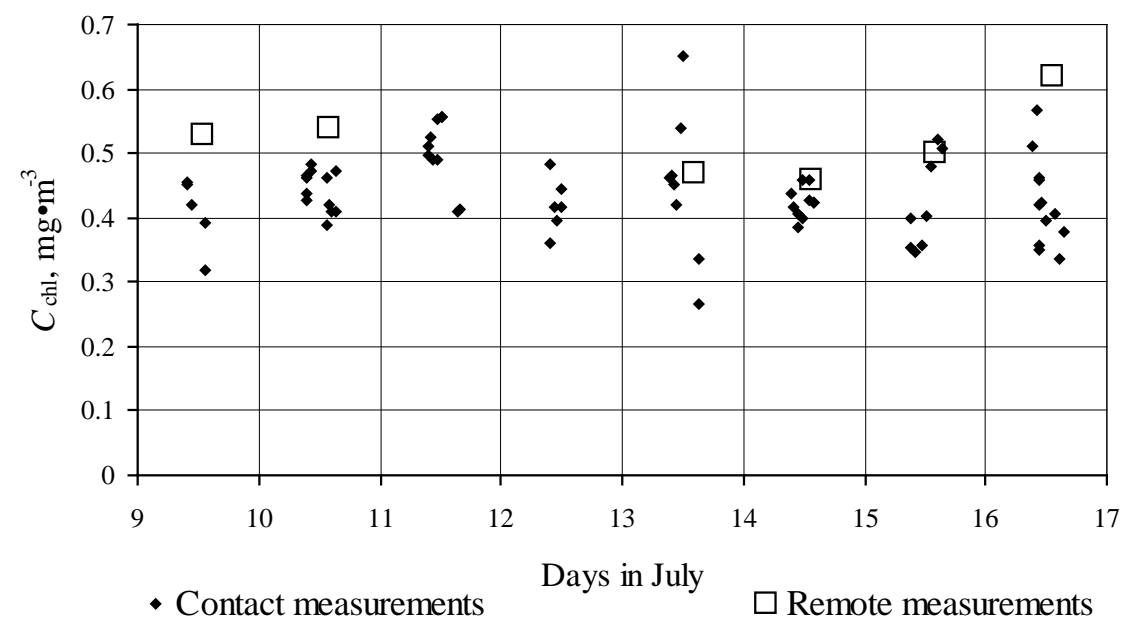

Fig. 7. Time dependence of the concentration of phytoplankton pigments in July 2012

After calculating the three parameters of the model it is possible to calculate the absorption spectrum of the pigments, which in contrast to the standard, will contain not only the maxima of chlorophyll. These maxima explain the difference between the measured seawater reflectance coefficient spectrum and spectrum calculated from the already known parameters $b_{\mathrm{bp}}\left(\lambda_{0}\right), C_{\mathrm{chl}}$ and $C_{\mathrm{ddm}}$. Such deviations occur in the narrow spectral bands, and generally do not affect the calculation of the parameters. The maximum of absorption at a wavelength of $412 \mathrm{~nm}$ (Fig. 8) can be correlated with the chlorophyll- $a$ decomposition products (chlorophyllide, pheophytin and others); at wavelengths of about $570 \mathrm{~nm}$, a maximum can be attributed to the presence of cyanobacteria in water containing phycoerythrin pigments. In addition, phycoerythrins have a maximum fluorescence at $575-585 \mathrm{~nm}$, which explains the sharp dip at wavelengths over $580 \mathrm{~nm}$ in the calculated absorption spectrum, as well as the appearance of negative values [29].
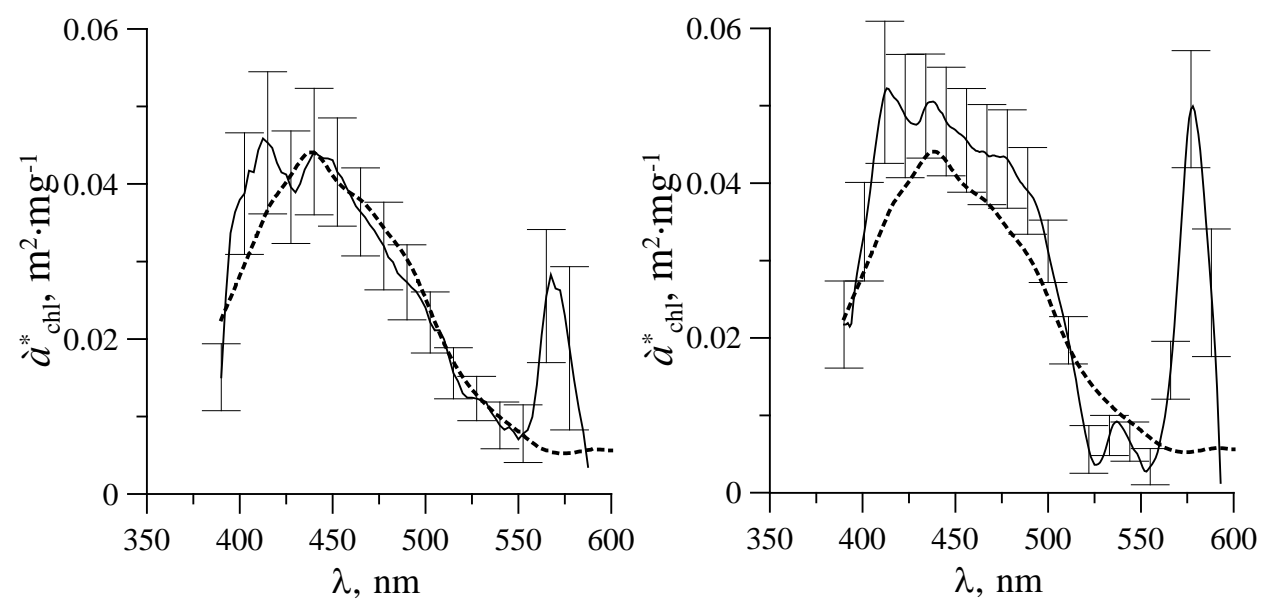

Fig. 8. Average absorption spectra of phytoplankton pigments (solid line) in July 2003 (left) and July 2012 (right). The dashed line shows a model spectrum [23]

PHYSICAL OCEANOGRAPHY NO. 6 (2015) 
The absorption spectra were calculated applying the following formula

$$
a_{\mathrm{chl}}^{*}(\lambda)=\frac{1}{C_{\mathrm{chl}}}\left[\frac{k b_{\mathrm{b}}(\lambda)}{\rho(\lambda)}-a_{\mathrm{w}}(\lambda)-C_{\mathrm{ddm}} \mathrm{e}^{-\alpha\left(\lambda-\lambda_{0}\right)}\right] .
$$

Specific absorption of phytoplankton pigments, calculated according to the contact measurement of the reflectance coefficient, has also the spectral values and behaviour typical for the summer season (Fig. 8). The presence of coccolithophore does not significantly change the spectrum shape and values of the absorption.

Calculations show that the obtained concentration of nonliving organic matter and backscattering of the suspension are weakly related with the concentration of chlorophyll- $a$ found applying certain biological methods. For example, according to the results of the experiment in September 2004, the average value $C_{\mathrm{ddm}}$ was $0.133 \mathrm{~m}^{-1}$, the average value $b_{\mathrm{bp}}\left(\lambda_{0}\right)$ equaled $0.0059 \mathrm{~m}^{-1}$. These values match well with the biological data of direct measurements of these quantities. According to the data of [27], the average value of dissolved organic matter absorption at a wavelength of $440 \mathrm{~nm}$ is $0.08 \mathrm{~m}^{-1}$, the absorption coefficient of detritus $\sim 0.06 \mathrm{~m}^{-1}$. Since the parameter $C_{\mathrm{ddm}}$ describes the total absorption of dissolved organic matter and detritus, a good match is observed between the measured and calculated values.

Measuring the backscattering coefficient using nephelometer, an average value of $0.0048 \mathrm{~m}^{-1}$ at a wavelength of $443 \mathrm{~nm}$ was obtained. When converting the retrieved values $b_{\mathrm{bp}}(400)$ to the wavelength of $443 \mathrm{~nm}$ under the spectral law used in the backscattering model, the value $0.0053 \mathrm{~m}^{-1}$, close to experimentally measured backscattering was obtained.

Processing the data collected during the bloom, it is important to select the original parameters of the mineral suspension scattering model, since it is the very factor having the greatest influence on the optical properties of seawater. Since there is no suspension separation in the coarse and fine fractions in the model, the parameter $b_{\mathrm{bp}}\left(\lambda_{0}\right)$ will determine the scattering of all the suspended mineral particles, regardless of size, i. e. by coccoliths, coccolithophore cells, as well as by the mineral suspension. Unchanged reflectance coefficient spectrum shape shows that the scattering increase was not accompanied by an increase of absorption, which is possible under the prevalence of a number of coccoliths over large particles suspension including cells. According to the literature data [28,30], under the circumstances observed the number of coccoliths is order of magnitude higher than the number of different mineral suspension, and two orders higher than the number of coccolithophore cells. Therefore, in this paper, the term "mineral suspension" means a mineral suspended matter containing coccoliths. The works $[28,31]$ mention that the spectral slope of backscattering of the mixture of coccoliths and coccolithophore cells $v$ is 0.8 .

To assess the extent of the bloom and number of the coccolithophore is possible according to the results of the calculation of suspension backscattering. In order to apply the empirical ratio from the work [31]

$$
b_{\text {b_cocc }}(546)=1,1 \cdot 10^{-13} N_{\text {cocc }} \text {, }
$$


relating the suspension (coccoliths) backscattering $b_{\mathrm{b} \_ \text {cocc }}(546)$ at wavelength $546 \mathrm{~nm}$ to the number density of coccoliths $N_{\text {cocc }}\left(\mathrm{m}^{-3}\right)$ obtained as a result of model analysis, the backscatterring $b_{\mathrm{bp}}(400)$ had been recounted to $546 \mathrm{~nm}$, taking into consideration the spectral course:

$$
b_{\mathrm{b} \_ \text {cocc }}(546)=b_{\mathrm{bp}}(400)(400 / 546)^{0,8} \text {. }
$$

Simultaneously the evaluation of the concentration of coccoliths from satellite data was carried out, namely according to the content of carbon in the mineral suspension (particulate inorganic carbon, pic, $\operatorname{mole}(\mathrm{C}) \cdot \mathrm{m}^{-3}$ ), being one of the standard MODIS scanner products. pic data were converted to the concentration of coccoliths by means of the following ratio

$$
\text { pic } \cdot \mu(\mathrm{C})=m_{\text {C_cocc }} N_{\text {сосc }} \text {, }
$$

where $\mu(\mathrm{C})-$ molar mass of carbon; $m_{\mathrm{C}_{-} \text {cocc }}=2 \cdot 10^{-13} \mathrm{~g}-$ carbon content in coccolith under the data [28].

Time dependence of the values $N_{\text {cocc }}$, obtained according to such evaluations is shown in Fig. 9. On the average the concentration value was $1.2 \cdot 10^{11} \mathrm{~m}^{-3}$, which corresponds to the concentration of coccolithophore cell about $10^{6}$ cells $\cdot l^{-1}$. The obtained concentrations of the mineral suspension, as well as the $3-4$ times higher than usual reflectance coefficients, indicate that the bloom observed has been one of the most intense in recent years [20].

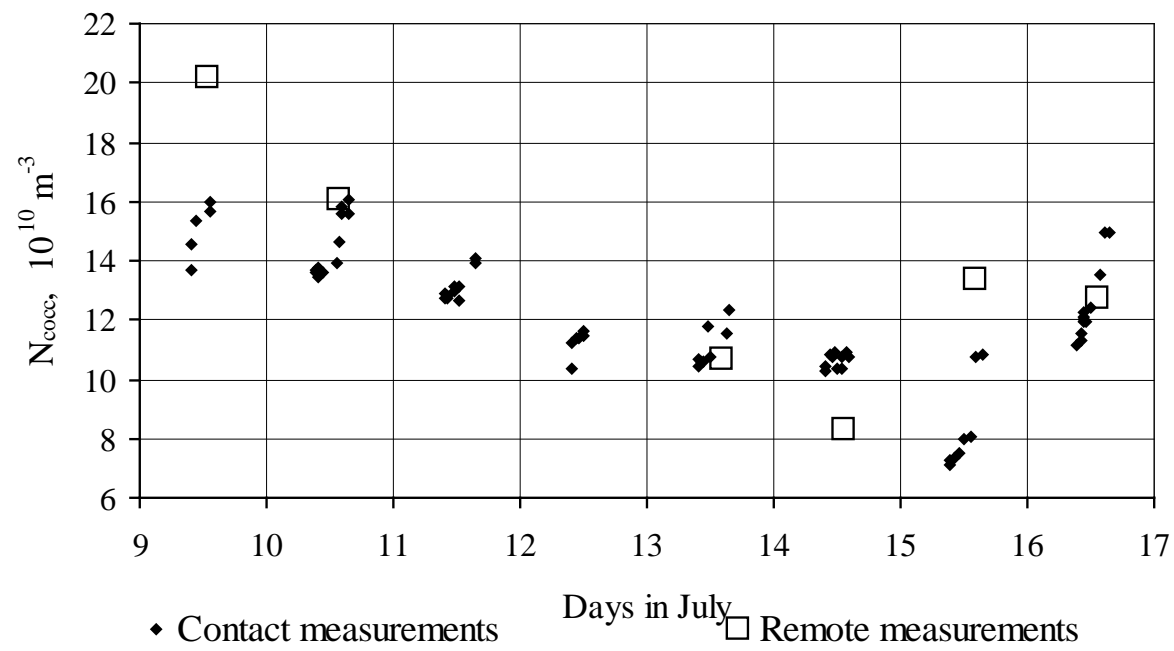

Fig. 9. Time dependence of the mineral suspension concentration

Conclusion. Spectrophotometer for seawater reflectance coefficient measurement, developed in the MHI Marine Optics Department, can solve a variety of marine biooptical problems, including the validation of satellite measurements. The construction of spectrophotometer enables it to be applied in a 
variety of experimental conditions, and the instrument does not require the absolute calibration. The measurement scheme is designed in such a way that allows accurately taking into account the light reflected by the sea surface, without any calculations and simulation concepts. In general, the instrument makes it possible quickly and efficiently characterize the biooptical state of the marine environment.

Data processing algorithm of the reflectance coefficient and calculation of the concentration of optically active impurities - phytoplankton pigments, suspension and nonliving organic matter - takes into account the characteristics of the optical properties of the research area. In addition, it uses the specially developed iterative procedure allowing to simplify calculations and making the solution of the inverse problem stable.

Obtained by means of the analytical algorithm values of chlorophyll- $a$ concentrations match well the data of direct measurements. As a result of the processing of the data obtained during subsatellite experiment (2002 - 2004), when the direct measurements of chlorophyll- $a$ concentration had been carried out, deviations of the analytically calculated concentrations of chlorophyll- $a$ from the measured ones were about $10 \%$.

The estimated concentration of chlorophyll- $a$ during coccolithophore bloom (July 2012) was $\sim 0.5 \mathrm{mg} \bullet \mathrm{m}^{-3}$, which is higher than the average values for the summer period [26]. The reason for this increase may lie in a mass development of other phytoplankton species along with coccolithophore, but this increase is consistent with the observations of other authors [28].

The estimated concentrations of the nonliving organic matter also match well the biological data and the backscattering by suspension - with the data of direct measurements of the scattering coefficient in 2004. The estimated concentration of the mineral suspension during coccolithophore bloom in 2012 was $\sim 1.2 \cdot 10^{11} \mathrm{~m}^{-3}$, corresponding under the order of values to the blooms fixed in 1992 and 2006. These data indicate that the observed bloom has been one of the most intense in recent years [20].

Since the reflectance coefficient spectrum is measured with a high resolution $(5 \mathrm{~nm})$ thereon specific absorption spectra of the pigments of phytoplankton can be calculated. Additional absorption maxima provide information about the presence of the auxiliary photosynthetic pigments in the water. Analytical algorithm permits to evaluate the presence of substances in the water, that are difficult to determine by the biological methods.

The resulting methodology can also be used for processing the reflectance coefficient spectra measured by satellite scanners during remote sensing of the Black Sea for the monitoring of the ecological state of the Black Sea basin.

Acknowledgements. The research was carried out in Marine Hydrophysical Institute RAS under the sponsorship of the Ministry of Education and Sciences of the Russian Federation within the framework of the FTsP "Research and Development in Priority Development Directions of the scientific-technological complex in the Russian Federation 2014 - 2020" (unique project code RFMEFI57714X0110) and RFBR (scientific project No. 14-45-01049 "Development of the Regional Algorithm for Estimation of the Black Sea Coastal Water Biooptical Features according to the Remote Probing Data”). 


\section{REFERENCES}

1. Pelevin, V.N., Lokk, Ya.F., Kel’balikhanov, B.F., 1975, "Fotometr dlya izmereniya spektral'noy yarkosti vykhodyashchego iz morya izlucheniya i rezul'taty ego ispytaniy $v$ naturnykh usloviyakh [Photometer for spectral brightness of the radiation coming from the sea and its test results under expeditionary conditions]", Opticheskie Issledovaniya $v$ Okeane $i$ Atmosfere nad Okeanom, Moscow, IOAN, pp. 126-134 (in Russian).

2. Afonin, E.I., Li, M.E., 1984, "Telefotometr dlya izmereniya yarkosti prirodnykh ob"ektov v vidimom diapazone spectra [Telephotometer for reflectance measurements of the nature objects in the visual spectral range]", Tez. dokl. Pyatoy vsesoyuznoy nauchno-tekhnicheskoy konferentsii "Fotometriya i ee metrologicheskoe obespechenie”, Moscow, VNIIOFI, pp. 115 (in Russian).

3. Morel, A., 1980, "In-water and remote measurements of ocean color”, Bound.-Lay. Meteorol., vol. 18 , no. 2, pp. 177-201.

4. Hooker, S.B., Lazin, G., Zibordi, G. [et al.], 2002, “An evaluation of above- and in-water methods for determining water-leaving radiances”, J. Atmos. Ocean. Technol., vol. 19, no. 4, pp. 486-515.

5. Toole, D.A., Siegel, D.A., Menzies, D.W. [et al.], 2000, "Remote-sensing reflectance determinations in the coastal ocean environment: impact of instrumental characteristics and environmental variability”, Appl. Opt., vol. 39, no. 3, pp. 456-469.

6. Weeks, A.R., Robinson, I.S., Booty, B., 1993, "A towed near-surface optical reflectance meter for measuring ocean colour in support SeaWiFS”, European workshop on optical ground truth instrumentation for the validation of space-borne optical remote sensing data of the marine environment, NIOZ-Raport., pp. 3-9.

7. Lee, Z.P., Carder, K.L., Haves, S.K. [et al.], 1996, "Method to derive ocean absorption coefficient from remote sensing reflectance”, Appl. Opt., vol. 35, no. 3, pp. 453-462.

8. Mueller, J.L., Zaneveld, J.R., Pegau, S., [et al.], 1996, "Remote sensing reflectance: preliminary comparisons between in water and above water measurements and estimates modeled from measured inherent optical properties”, Ocean Optics XIII, Proc. of SPIE., no. 2963, pp. 502-507.

9. Olszewski, J., Darecki, M., 1999, "Derivation of remote sensing reflectance of Baltic waters from above-surface measurements”, Oceanologia, vol. 41, no. 1, pp. 99-111.

10. Artemiev, V.A., Burenkov, V.I., Vortman, M.I. [et al.], 2000, "Sea-truth measurements of ocean color: a new floating spectroradiometer and its metrology”, Oceanology, vol. 40, no. 1, pp. $139-145$.

11. Khrapko, A.N., Kopelevich, O.V., Burenkov, V.I. [et al.], 2007, “New instrument for measuring surface and underwater irradiances”, Proc. IV International Conf. Current Problems in Optics of Natural Waters, Nizhny Novgorod, pp. 271-275 (in Russian).

12. Smith, R.C., Menzies, D.W., Booth, C.R., 1996, "Oceanographic bio-optical profiling system II”, Ocean Optics XIII, Proc. of SPIE, vol. 2963, pp. 777-789.

13. Zibordi, G., Mélin, F., Hooker, S.B. [et al.], 2004, "An autonomous above-water system for the validation of ocean color radiance data”, IEEE Trans. Geosci. Rem. Sens., vol. 42, no. 2, pp. 401-415.

14. Zibordi, G., Berthon, J.-F., Mélin, F. [et al.], 2009, "Validation of satellite ocean color primary products at optically complex coastal sites: Northern Adriatic Sea, Northern Baltic Proper and Gulf of Finland”, Rem. Sens. Environ., vol. 113, no. 12, pp. 2574-2591.

15. Li, M.E., Martynov, O.V., 2000, "Izmeritel' koeffitsientov yarkosti dlya podsputnikovykh izmereniy bioopticheskikh parametrov vod [Reference coefficient meter for subsatellite measurements of the water biological parameters]", Ekologicheskaya bezopasnost' pribrezhnoy i shel'fovoy zon i kompleksnoe ispol'zovanie resursov shel'fa, pp. 163-173 (in Russian).

16. Mobley, C.D., 1999, "Estimation of the remote-sensing reflectance from above-surface measurements", Appl. Opt., vol. 38, no. 36, pp. 7442-7455.

17. Lee, Z.P., Ahn, Y.H., Mobley, C. [et al.], 2010, "Removal of surface-reflected light for the asurement of remote-sensing reflectance from an above-surface platform”, Optics Express. vol. 18, no. 25, pp. 26313-26324. 
18. Yasakova, O.N., Stanichniy, S.V., 2012, “Anomal'noe tsvetenie Emiliania Huxleyi (Prymnesiophiceae) v Chernom more v 2012 godu [Anomalous Emiliania Huxleyi (Prymnesiophiceae) Bloom in the Black Sea in 2012]”, Morskoy ekologicheskiy zhurnal, vol. 11, no. 4, p. 54 (in Russian).

19. Balch, W.M., Kilpatrick, K.A., Holligan, P.M. [et al.], 1996, "The 1991 coccolithophore bloom in the central North Atlantic. II. Relating optics to coccolith concentration”, Limnol. Oceanogr., vol. 41, no. 8, pp. 1684-1696.

20. Mikaelyan, A.S., Silkin, V.A., Pautova, L.A., 2011, "Coccolithophore development in the Black Sea: interannual and long-term changes”, Oceanology, vol. 51, no. 1, pp. 45-53.

21. Shibanov, E.B., 2005, "Chislennyy metod resheniya uravneniya perenosa. Koeffitsienty otrazheniya i propuskaniya opticheski tonkogo ploskoparallel'nogo sloya [Numerical method of transport equation solution. Optically thin plain-parallel layer reflectance and transmission coefficients]”, Morskoy gidrofizicheskiy zhurnal, no. 3, pp. 62-71 (in Russian).

22. Pope, R.M., Fry, E.S., 1997, “Absorption spectrum 380-700 nm of pure water. II. Integrating cavity measurements”, Appl. Opt., vol. 36, no. 33, pp. 8710-8723.

23. Bricaud, A., Babin, M., Morel, A. [et al.], "Variability in the chlorophyll-specific absorption coefficients of natural phytoplankton: Analysis and parameterization”, J. Geophys. Res., vol. 100, no. C7, pp. 13321-13332.

24. Korchemkina, E.N., Shybanov, E.B., 2009, "Special minimization technique for analytical algorithms of chlorophyll retrieval", Proc. V International Conf., Current problems in optics of natural waters, Saint Petersburg, pp. $73-77$ (in Russian).

25. Chami, M., Shybanov, E.B., Churilova, T.Y. [et al.], 2005, “Optical properties of the particles in the Crimea coastal waters (Black Sea)”, J. Geophys. Res., vol. 110, no. C11, pp. 1-17.

26. Churilova, T.Ya., Berseneva, G.P., 2004, "Pogloshchenie sveta fitoplanktonom, detritom i rastvorennym organicheskim veshchestvom $v$ pribrezhnom rayone Chernogo morya (iyul'avgust $2002 \mathrm{~g}$.) [Light absorption by phytoplankton, detritus and dissolved organic matter in the Black Sea coastal area (July-August 2002)]”, Morskoy gidrofizicheskiy zhurnal, no. 4, pp. 39-50 (in Russian).

27. Churilova, T., Suslin, V., Berseneva, G. [et al.], 2007, "Parameterization of light absorption by phytoplankton, nonalgal particles and coloured dissolved organic matter in the Black Sea”, Proc. IV International Conf. Current problems in optics of natural waters, Nizhny Novgorod, pp. 70-74 (in Russian).

28. Balch, W.M., Holligan, P.M., Ackleson, S.G. [et al.], 1991, "Biological and optical properties of mesoscale coccolithophore blooms in the Gulf of Maine”, Limnol. Oceanogr., vol. 36, no. 4, pp.629-643.

29. Rowan, K.S., 1989, "Photosynthetic Pigments of Algae”, Cambridge, Cambridge University Press, 334 p.

30. Voss, K.J., 1998, "Scattering and attenuation properties of Emiliania huxleyi cells and their detached coccoliths”, Limnol. Oceanogr., vol. 43, no. 5, pp. 870-876.

31. Man'kovskii, V.I., Vladimorov, V.L., Afonin, E.I. [et al.], “Mnogoletnyaya izmenchivost' prozrachnosti vody $v$ Chernom more i faktory, obuslovivshie ee sil'noe snizhenie v kontse 80kh-nachale 90-kh godov [Long-term Black Sea water transparence and the factors, which caused its heavy reduce in the late 80s-early 90s]”, Sevastopol, 32 p. (in Russian). 